\title{
'Bio-bordering' processes in the EU: de-bordering and re-bordering along transnational systems of biometric database technologies
}

\author{
Nina Amelung* and Helena Machado \\ Communication and Society Research Centre (CECS), \\ University of Minho, \\ R. da Universidade, 4710-057 Braga, Portugal \\ Email: Nina.amelung@ics.uminho.pt \\ Email: hmachado@ics.uminho.pt \\ *Corresponding author
}

\begin{abstract}
Biometric data is increasingly flowing across borders in order to limit and control the mobility of selected people not only for migration control but also for crime control. The promise is that while data is mobilised, those declared outlaws will be immobilised. In this article, we discuss reverse patterns of bordering and ordering practices linked to large-scale transnational biometric database infrastructures. We introduce the concept of bio-bordering, using it to capture how the territorial foundations of national state autonomy are partially reclaimed and, at the same time, partially purposefully suspended when establishing biometric data exchange. The case of the Prüm system, the mandatory exchange of forensic DNA data amongst the EU member states, serves to portray instances of overcoming and enforcing bio-borders for data flows. Firstly, we explore the different logics of creating permeable bio-borders at work at the EU level which derive from EU attempts of integrating legal, scientific, technical and organisational dimensions. Secondly, we take the Portuguese case as an illustrative example of how latently reinforcing bio-borders counters the ambition of expansive data exchange.
\end{abstract}

Keywords: bio-bordering; re-bordering and de-bordering; modes of ordering; forensic DNA data exchange; border regimes; European Union.

Reference to this paper should be made as follows: Amelung, N. and Machado, H. (2019) "Bio-bordering' processes in the EU: de-bordering and re-bordering along transnational systems of biometric database technologies', Int. J. Migration and Border Studies, Vol. 5, No. 4, pp.392-408.

Biographical notes: Nina Amelung is a Post-doctoral Research Fellow with the 'EXCHANGE - Forensic Geneticists and the Transnational Exchange of DNA data in the EU: Engaging Science with Social Control, Citizenship and Democracy' project, funded by the European Research Council, led by Professor Helena Machado and based at the Communication and Society Research Center (CECS), University of Minho, Portugal. Her current research is on the democratic challenges of cross-border biometric data-exchange, and explores the making of publics in European crime, migration and border control regimes. She applies perspectives offered at the intersection of science and technology studies and political sociology. 
Helena Machado is a Full Professor of Sociology at the University of Minho, Portugal. In 2015, she was awarded a Consolidator Grant from the European Research Council (ERC) to conduct research into the societal, ethical, and political challenges posed by transnational exchange of forensic DNA data in the context of policing and judicial cooperation in the EU. She is presently studying the interrelationships between genetic surveillance, public trust and national identities.

This paper is a revised and expanded version of a paper entitled 'The making of invisible 'bio-borders' in the EU. Implications on configuring categories of risk in Portugal' presented at Workshop 'Bordering - A View from Portugal Migration and Border Making in Portugal', Universidade Nova, FCSH, Lisbon, 14-15 December 2017.

\section{Introduction}

Cross-border surveillance and data sharing for law enforcement are vital elements of the European Union (EU) systems in the area of freedom, security, and justice. In the last decades, EU surveillance practices have rapidly expanded with the creation of large-scale information technology (IT) database systems. The Schengen information system (SIS), the EURODAC database, the common visa information system (VIS), the Prüm system and, more recently, EUROSUR ${ }^{1}$ are prominent examples. IT is used to collect, store, compare and exchange diverse kinds of data. These intelligence networks are a result of the EU's policy of interoperability (Broeders, 2007), designated to enforce the practicable exchange of data between national and EU databases (Curtin, 2018). Preventing and investigating cross-border crime (i.e., terrorism, human trafficking, drug smuggling and illicit arms traffic) has been, at the discursive level of policy formation, the main driving force and justification for most of these crime investigating regimes [Aas, (2011), p.337]. Although practically all of these technologies aim to track and control mobility, some of them - such as the Prüm system - are intended primarily to support transnational criminal investigations (Machado and Granja, 2018).

This article explores the ambiguities of borders in cross-border data exchange. On the one hand, borders become permeable for effective and expansive data flows in the name of increased security and the control of selected people's mobility. On the other hand, member states enforce their territorial borders with logics that serve their citizens, for example, to protect national data subjects and to be accountable to national electorates.

The development of transnational systems for the mass exchange of biometric data ${ }^{2}$ at and across borders has challenged conventional notions of borders. Traditional border studies assumed state and territory borders were both fixed and the physical outcome of political, social or economic processes (Kolossov and Scott, 2013). In this paper, we suggest a perspective that takes into consideration the contingencies that derive from the practices found among heterogeneous actor networks involved in bordering practices of referring to the nation-state. 
We follow impulses from border studies that have turned to approaches that understand borders not as given, but as continuously 'being made' and involving b/ordering practices (van Houtum et al., 2005; Kolossov and Scott, 2013). By understanding borders as emerging through socio-political as well as techno-scientific processes, the emphasis lies in understanding bordering as taking place within society (Kolossov and Scott, 2013). We build on a notion of state borders that understands them as elastic, dynamic and situated processes, multiplied and enforced by the various practices of multiple actors and institutions far beyond their physical sites. We use that notion of elasticity of borders also to demonstrate that border regimes for digital biometric data are distinct from border regimes for people. Therefore, we argue that it is essential to rethink earlier conceptual approaches that take the emergence of digital and biometric borders as a static, functional given, built on the 'sharply bounded territorial containers associated with classical modernity' (van Houtum et al., 2005). These classical approaches tend to consider the virtual and digital dimension only as a new form of communication (Löw and Weidenhaus, 2017), and biometrics as an efficient identification mechanism for creating 'smart borders' (Lehtonen and Aalto, 2017).

In order to contribute to improving the conceptual apparatus beyond the world of fixed, contained state borders, we introduce the concept of 'bio-bordering'. We use it to explore the modes of ordering biometric data applied in criminal investigation that have consequences for people of suspicion moving across nation-states' borders. The consequences we consider here are those which derive from storing and exchanging data from individuals, who then become data subjects, with - as we show in our article differently granted rights across national regimes. The concept focuses, first, on biometrics as an inherently classifying and thus boundary-making mechanism when identifying selected 'risky' people. Furthermore, the concept links to the 'bio' prefix a notion of borders that assumes 'distributed agency' in heterogeneous networks that include security professionals and biometrics experts enacting, overcoming or reinforcing nation states' borders along biometric data in unexpected manners. We argue that the concept of bio-bordering is particularly useful in trying to understand the modes of ordering entangled with transnational large-scale IT database infrastructures for the exchange of biometric data in the context of crime control ${ }^{3}$.

We portray the bio-bordering processes in the EU as contributing simultaneously to what Misa and Schot (2005, p.3), reflecting on technological infrastructures, have called the 'hidden integration' and 'hidden fragmentation' of Europe. Using the lens of technology, the authors situate European integration as an emergent outcome of a contested process of linking and delinking of infrastructures, as well as the circulation and appropriation of artefacts, systems, and knowledge, which produces integration and fragmentation at the same time (ibid). In the case of biometric technologies in the area of freedom, security, and justice, the hidden integration takes place through the standardisation and homogenisation of biometric scientific standards, as well as through technical and operational infrastructures, which thereby establish a transnational forensic technocracy (Prainsack and Toom, 2010). Yet, we explore in this paper also the processes of hidden fragmentation that result from the establishment of rigid bio-borders that are only selectively permeable for data flows and thus counter the ambition of expansive biometric data exchange. This fragmentation is materialised in forms of heterogeneous national regimes regulating data protection and mechanisms to hold biometric cross-border data exchange accountable to the public. 
We discuss in this paper the example of the Prüm system, designed for the transnational exchange of DNA data for forensic and police use. Furthermore, we present the political attempts to secure the unhindered flow of biometric data among the member states that are mobilising a mode of ordering aimed at diminishing technical and legal obstacles. Then we discuss the case of Portugal, which employs a protective bio-borders mode of ordering concerning its forensic DNA database and its approach to making DNA data accessible for transnational exchange. Thereby, we explore the regulatory, material and organisational contingencies that derive from the national context and the ambiguities and tensions that derive from contradictory bio-bordering dynamics.

The article begins by outlining the notion of bio-bordering by reflecting on insights from recent developments in border studies. The article then introduces the transnational DNA data exchange system regulated by the Prüm system and portrays how political and regulatory ambitions have translated into permeable bio-borders. We then proceed to explore the situation in Portugal, as an example of how national arrangements result in the latent re-bordering of bio-borders. In the conclusion we discuss how, by making invisible bio-borders visible, our approach helps to uncover the implications of multiple processes of overcoming and enforcing bio-borders in the context of the hidden fragmentation related to contemporary security policies in the EU.

\section{Theorising bio-borders and the de(b)ordering and re(b)ordering of bio-borders}

Acknowledging the increased use of biometric technologies has forced scholars to reconsider 'the border' in contemporary political life. Biometrics provides the ground for sorting and classifying individuals and groups into legal/illegal or welcome/unwanted persons, and for controlling migration by filtering desired and undesired mobility (Amoore, 2006; Aas, 2011). The inclusion/exclusion dichotomy and the processes of othering have been of high relevance in border studies, which aims to provide clarification and more in-depth understanding of the inherent dynamics and ambivalent qualities of such categories and their primary ordering ability to make boundaries (Dijstelbloem and Broeders, 2015). Biometric technologies are also being used to help control transnational crime and identify transnational suspects 'in light of fears of an "escalation of cross-border crimes" (Prainsack and Toom, 2010). The ability of biometric technologies to transform the body's characteristics into digital codes that can be 'read' by a machine (Aas, 2011; van der Ploeg, 1999) means that biometric data can be stored in large databases. Biometrics and databasing together have a secondary ordering ability to track mobile bodies across borders for surveillance purposes.

Digital borders have been characterised by Dijstelbloem and Broeders (2015, p.23) as a 'new form of mobility control', one which combines the function of 'politics at a distance' (Latour, 1987, 2005) with 'virtual data collection' to result in 'a logic of the extraterritorial net of control' [Tsianos and Karakayali, (2010), p.374]. Tsianos and Kuster (2016) examine the example of Eurodac, which they not only understand as a technological border but as inflected by social, symbolic, organisational and juridical cultures, practices and imaginaries that are beyond the literal realm of the electronic space. The current technological mediation of borders requires the labour of software developers, designers, engineers, infrastructure builders, border guards, systems experts, 
and many others, all of whom help produce digital borders (Vukov and Sheller, 2013). We propose that we need an approach that aims to take both biometrics and digitalisation equally seriously.

We introduce the term 'bio-border' to explore how the establishment of transnationally applied biometric technologies - which comes explicitly with the regulation of how biometric data may (not) cross borders - produces implicitly a multiplicity of historically contingent and intentional re-ordering processes that partially overcome and partially reinforce nation states' territorial borders through bodies, data, and technology.

The particularity of such border-crossing modes of ordering lies in their attempts to track the mobility of certain people across state borders in the context of crime control, or to identify people related to crimes, including victims and missing persons. The implicit assumption is that the more data is exchanged, the more useful it is. In addition, the expected benefit of such technologies is to guarantee the security of societies. On the one hand, transnational biometric technology systems are enacted as attempts to expand biometric data exchange and establish 'borderlessness' for data flows and to overcome the logics of nation state boundaries. The aim of such border-crossing modes of ordering is to diminish technical, scientific, operational and legal obstacles, resulting in increasingly permeable bio-borders. On the other hand, the nation state's situated modes of ordering may reclaim the territorial foundations of the state's autonomy through the creation or maintenance of its own systems for collecting, sharing and protecting biometric data. Such systems thereby remain contingent on their own historically and culturally shaped political-judicial path of biometric technology and database development.

Bio-borders are understood, in the first place, as historically grown boundaries separating different national systems of biometric data collection. In order to allow biometric data to cross a nation state's territorial borders, bio-borders need to become reordered and constructed in a way that interconnects national infrastructures of regulatory, biometric, IT and organisational dimensions dedicated to the retention of biometric data. The ambition to create expansive biometric data exchange requires what we call the de-bordering of the historically grown bio-borders, that is, making bio-borders permeable and data available across borders. At the same time, when confronted with requirements to make their data available, actor networks in the member states respond by raising a diverse range of concerns over data protection, technical-infrastructural problems, and the need to install appropriate safeguards and oversight to prevent malfunctions of the data-exchange systems. In consequence, member states may create conditions that reinforce bio-borders, what we call re-bordering, by making them only selectively permeable and by putting data border-crossings under stricter regimes of control. Two clarifications on our understanding of re-bordering in this article are essential. First, re-bordering can be enforced through interactions with biometric techno-scientific and IT databasing infrastructures. Second, re-bordering is not necessarily a deliberately coherent and intentional process designed by the whole actor-network to close bio-borders; instead, it can be an ambiguous process deriving from the intentions of some actor groups with specific concerns, while other actor groups are committed to contributing to expanding data exchange. 
In this paper, we take inspiration from Johnson et al. (2003, p.26). The authors focus on four constitutive components of national criminal DNA databases and data exchange flows across them. First, the regulations, legislative frameworks and governance principles of the countries sanctioning the collection, use and retention of DNA data, including data protection regimes. Second, DNA technology, including the scientific knowledge that DNA technologies build on, material artefacts and biological resources like samples and paperwork, and methods for the representation of DNA variation in the form of standardised individual profiles that can be compared. Third, the technical database infrastructure necessary to digitally store and compare data, and the definition and management of which data categories are and are not made accessible for data exchange. Fourth, the organisational imperatives and principles, such as reliability, transparency and public accountability, which translate into work routines that include taking biometric samples, inputting data, reporting hits, following up correspondence in case of matches, and providing transparent and publicly available statistics.

In consequence, we understand bio-borders as constituted and configured by the following border infrastructures: legal and regulatory, techno-scientific biometrical, IT database and organisational particularities. Together they create boundaries around national regimes of biometric-data retention and distinguish them from others. In order to study bio-borders we propose to focus on the simultaneous multiple processes carried out by a heterogeneous actor-network of regulators, security professionals, forensic technocratic experts, and other criminal justice systems' stakeholders involved in national biometric-data collection and retention and in operational data exchange who jointly contribute to the reordering and remaking of bio-borders.

Our perspective is distinct in that it shifts understanding away from notions of the EU or the member states as coherent rational and intentionality driven actors towards the distributed, yet collective, agency of a heterogeneous set of actors with different potentially even conflicting - co-existing nation-state referencing rationalities. These actors include those involved in the technoscience of biometrics (Latour, 1987). In sum, bio-bordering practices produce a particular outcome with concrete consequences for targeted people, data subjects and those whose data gets exchanged on the one hand and for societies' security on the other. There is a methodological problem in the attempt to investigate how data mobility produces such consequences because there is little public data available about how these new types of data-exchange systems impact on the mobility of targeted people and actual data subjects. For instance, there is little information on the impact of such systems on deterring criminals, and we also know little about actual improvements to societies' security (Toom, 2018).

In the following, we explore the bio-bordering processes between the EU and Portugal, focusing, in particular, on the Prüm system, which regulates the transnational exchange of DNA data for forensic and police use in the EU. First, we illustrate the EU's efforts to guarantee the establishment and implementation of the Prüm system in all participating EU member states. We portray it as a mode of ordering that results overall in making bio-borders permeable for expansive data exchange across the member states. Second, we choose to portray Portugal as a case in which bio-borders are latently enforced. It happens through a process in which the requirements of the respective EU regulations are fully implemented, while the ways of making biometric data accessible are defensively and restrictively ordered. 


\section{De-bordering at the EU level}

The Prüm Treaty (Council of the European Union, 2005) aimed to establish a framework to simplify, coordinate and improve the circulation of information between the EU member states' law enforcement agencies. Specifically, the Treaty aimed to intensify cross-border cooperation through the automated exchange of information - namely DNA profile data, fingerprints, and vehicle registration data - between the member states. After the Treaty was incorporated into the EU's legal framework on 23 June 2008, through Decisions 2008/615/JHA and 2008/616/JHA (Council of the European Union, 2008a, 2008b), all member states were obligated to build and maintain the technical infrastructure needed for the implementation of DNA databases. They were also required to enact adequate legislation to set up the operational requirements needed to establish connections with other member states and exchange data (Sallavaci, 2015, 2017). In the EU, DNA databases are mostly dedicated to the storage of DNA profiles collected for criminal investigation purposes, although some also serve the purposes of civil identification, for example, in cases of missing persons or mass disasters (Williams and Wienroth, 2014). The mode of ordering of bio-borders here implies the enabling and facilitation of biometric and personal data flows across the EU member states, to identify mobile persons suspected of crime or terrorism.

In order to enforce a de-bordered version of bio-borders, in 2016 the European Commission also used the instrument of the infringement procedure. This instrument formally communicated to certain countries - Portugal, Italy, Croatia, Greece and Ireland - that they were not in compliance with the Prüm's rules. These rules outlined that member states' regulations and technical infrastructures should allow and enable other member states to search DNA analysis files, fingerprint identification systems, and vehicle registration databases. The European Commission highlighted that the Prüm Decisions should have been implemented fully by the member states by August 2011, and that these member states had not yet ensured automated data exchange in at least two of the three types of data. Given that the Treaty of Lisbon ${ }^{4}$ gave the Commission full enforcement powers in the field of police cooperation and judicial cooperation in criminal matters, countries like Portugal, Croatia, Italy, and Ireland would need to comply in order to avoid the case being referred to the Court of Justice of the European Union (Commission of the European Union, 2016).

While the Prüm Treaty and Decision made it mandatory for EU member states to have a forensic DNA database and to be able to exchange DNA data with as many other member states as possible, advocates of diminishing bio-borders also have an interest in the overall expansion of the biometric data available for exchange. In this regard, the European Network of Forensic Science Institutes [ENFSI DNA Working Group, (2017), p.7], as a central player in the European epistemic community of forensic genetics contributing to the de facto harmonisation and standardisation of technical and scientific standards and protocols across Europe, recommends that:

To increase the chance of identifying the donors of stains, the number of persons in a DNA database who are likely to be the donors of those stains should be as large as legally (and financially) possible.

Connecting member states' DNA databases brings in diverse contingencies, some of which derive from the diverse legal traditions and regulations governing forensic DNA databases among the member states. According to Santos et al. (2013), we find two main tendencies: On the one hand, an 'expansive' group of countries that have few restrictions 
on the inclusion of profiles combined with long periods of retention. On the other hand, a 'restrictive' group of countries, where the criteria for inclusion include suspicion or conviction of particular crimes, the length of any potential prison sentence, or a decision by a magistrate, and where retention periods tend to be smaller than in the first group (Santos et al., 2013). In spite of the ECHR's decision in favour of data protection for individuals, views on data protection depend on member states' policy agendas. In consequence, the diversity of approaches have implications for the (in)equality of conditions for the exchange of DNA data. The different criteria for inclusion and exclusion across the EU member states create unequal consequences for targeted people and data subjects. It creates a situation where it is possible that a DNA profile from an individual legally included in the database of one country is compared against the database of another where the legal regime would not have allowed its inclusion (Santos, 2017; Wilson, 2016).

Another contingency regarding such modes of ordering comes with the biometric technologies at stake. Although minimum technical/scientific standards have been established, applied DNA technologies remain prone to error, and the production of adventitious hits - so-called false positives (Van der Beek, 2011) - is a risk. ENFSI DNA Working Group (2017, p.30) warns:

As DNA databases become larger, the chance of adventitious matches occurring also increases, especially with partial and mixed profiles and the DNA profiles of relatives, which have higher random match probabilities.

Although safety measures have been installed to minimise the risk, the EU Commission continues to admit there is a problem with false positives. As part of 'Step 2', which is the follow-up procedure to a match and involves the exchange of personal data, of the Prüm system, the Commission has made recommendations about procedures that the member states should carry out before personal data is exchanged. Yet, tackling the problem through recommended procedures delegates the responsibility to member-state-based DNA laboratories and National Contact Points, each of which has varying access to staff resources, and different working routines and ethics (Machado and Granja, 2018; Taverne and Broeders, 2015). Forensic practitioners operating the Prüm system view the risk of false positives as ethically problematic because there is a lack of procedures for establishing the criteria for both reaching agreements and resolving disputes about what constitutes a reliable match both at local level and between different member states (McCartney, 2014; Machado and Granja, 2018).

Computing technologies are required to digitally store and compare DNA data. These technical database infrastructures bring together the distribution of particular ontologies that emphasise a numeric view on data exchange and highlight a notion of success measured by the quantitative amount of hits resulting from the comparison of DNA profiles across countries (Prainsack and Toom, 2010, 2013). Forensic geneticists involved in data exchange aim to enable a productive data flow - measured by the number of relevant connections with other countries and the creation of a relevant number of hits (Machado and Granja, 2018). However, this aim faces two challenges. First, being decentralised, it is difficult for the Prüm database system to trace information on any 'success' measured in terms of a subsequent effective criminal investigation. Besides, member states are differently connected (Santos and Machado, 2017): not only does the number of overall connections across particular member states differ, but the data categories classifying the type of DNA profiles exchanged across the member states vary enormously. Data categories related to the DNA profiles being exchanged within the 
Prüm system cover a wide range from convicted persons, suspects, crime stains, victims, unidentified persons, unidentified human remains, missing persons, relatives of missing persons and others (see Table 1).

Table 1 Categories of data and how member state restrict or allow access for automated data exchange

\begin{tabular}{|c|c|c|}
\hline Data category & Countries using category & $\begin{array}{c}\text { Number of } \\
\text { countries using } \\
\text { category }\end{array}$ \\
\hline 'crime stains' & $\begin{array}{l}\text { BE, BG, CZ, DK, DE, EE, EL, ES, FR, CY, LV, LT, LU, } \\
\text { HU, MT, NL, AT, PL, PT, RO, SI, SK, FI, SE, UK, NO }\end{array}$ & 26 \\
\hline 'suspects' & $\begin{array}{l}\text { BE, CZ, DK, DE, EE, EL, ES, FR, LV, LT, HU, MT, } \\
\text { NL, AT, PL, RO, SI, SK, FI, SE, NO }\end{array}$ & 21 \\
\hline $\begin{array}{l}\text { 'convicted' } \\
\text { persons }\end{array}$ & $\begin{array}{c}\text { BE, BG, CZ, DK, EE, ES, FR, CY, LV, LU, HU, NL, } \\
\text { AT, PT, RO, SK, FI, SE, UK, NO }\end{array}$ & 20 \\
\hline $\begin{array}{l}\text { 'unidentified } \\
\text { human remains' }\end{array}$ & $\begin{array}{c}\text { BG, CZ, DK, DE, EE, ES, FR, CY, HU, NL, AT, PL, } \\
\text { RO, SI, SK, UK }\end{array}$ & 16 \\
\hline $\begin{array}{l}\text { 'unidentified } \\
\text { persons' }\end{array}$ & CZ, EE, ES, FR, CY, LV, LT, MT, NL, AT, PL, RO, SK & 13 \\
\hline $\begin{array}{l}\text { 'missing } \\
\text { persons' }\end{array}$ & CZ, DK, EE, LV, NL, AT, PL, RO, SI, SK & 10 \\
\hline $\begin{array}{l}\text { 'relatives of } \\
\text { missing } \\
\text { persons' }\end{array}$ & SI & 1 \\
\hline 'victims' & SK & 1 \\
\hline
\end{tabular}

Source: Own composition based on Council of the European Union (2018)

According to the information provided by the Council of the European Union at the beginning of 2018, Portugal and Luxembourg allow the other member states the least access to their data in terms of data categories (Council of the European Union, 2018). They only provide access to two categories of data: DNA profiles of 'convicted' and 'crime stains'. Other operational countries share three or more data categories. The most common categories exchanged with other countries are: 'suspects' (shared by 21 out of 27 countries); 'crime stains' and 'convicted' persons (shared by 20 out of 27 countries); and 'unidentified human remains' (shared by 16 out of 27 countries).

There is also diversity in how each member state organises the work of data exchange. This diversity is then also expressed in the practices related to the follow-up correspondence when matches occur. Processes also take place very differently because of the diverse range of authorities involved - from judicial authorities to police forces given custody of particular entities within the national DNA databases. In the vast majority of the member states involved in the Prüm system, the Ministry of the Interior (which is occasionally called Ministry of Internal Affairs or Home Affairs) has custody of the database. However, in some member states - Belgium, Netherlands, Portugal, and Sweden among them - the DNA database is in the custody of the Ministry of Justice, which is in charge of organising the justice system and overseeing the public prosecutor. Previous studies indicate that transnational cooperation between police forces tends to be faster and less restrictive in terms of data protection than cooperation between the judicial authorities of different countries (McCartney, 2017; Perras, 2017). 
Another difference derives from the translation of particular governance principles, such as public accountability, into routines to provide transparent and publicly available information and statistics regarding the national involvement in the Prüm system, as suggested by ENFSI:

Because DNA databases have a very important yet very delicate role in society, the custodian of a DNA database should develop tools to make objective information about the DNA database available to politicians, the public and the media [ENFSI DNA Working Group, (2017), p.49].

Among the EU member states, Sweden, the Netherlands, Belgium, and Portugal have at least collected and made information publicly available in the form of annual reports and websites [see ENFSI DNA Working Group, (2017), p.48].

Summing up, at the EU level, we find a levelling mode of ordering at work that aims to diminish the technical and legal obstacles that contribute to de-bordered bio-borders. Furthermore, political and legal entities are aiming to harmonise crime control across the member states through common scientific-technical standards applied in the exchange of DNA data and materialised in the digital infrastructure of a decentralised database system. The Prüm system at the EU level enacts a version of bio-borders, increasing their permeability across states and thus fostering a hidden integration through technology. However, at the same time - as we will see in the next section - this creates diverse and ambiguous effects in some member states.

\section{Re-bordering dynamics at the national level}

The Portuguese national forensic DNA database was established in 2008. Law 05/2008 determined that the Institute of Forensic Medicine should run the database, and it provided the basis for one of the most restrictive regulatory frameworks in Europe concerning to the criteria for inclusion of profiles and the length and conditions of their retention and/or deletion (Machado and Silva, 2010). Only the DNA profiles of convicted offenders sentenced to three years or more in prison can be inserted into the database, and even then a judge's order is required. The DNA profiles of convicted persons are removed a maximum of ten years after the sentence has been completed. Samples are meant to be destroyed on collection or at the same time as the profile [Wallace et al., (2014), p.60]. In addition, the transnational exchange of genetic data requires the authorisation of a judge (former article $21^{\circ}$ of Law 5/2008, now article $21^{\circ}$ of Law $90 / 2017$ ), and all the activities related to the exchange of DNA data and other operations related to the national DNA database are audited by an ethics committee (Conselho de Fiscalização) which reports to the Portuguese parliament (Machado and Silva, 2009, 2010). Due to those conditions, Portugal has been identified as one of the 'restrictive countries', as opposed to the 'expansive countries', with regard to its legislative framework for regulating inclusion and retention of DNA profiles in its database (Santos et al., 2013).

Although Portugal obtained observer status in 2006 and began participating in the work meetings provided in the Prüm Agreement (Gabinete do Secretário - Geral, 2006), and was authorised in 2011 by the EU Council to exchange data, the country only began to connect with the Prüm system's genetic data exchange in August 2015 (Council of the European Union, 2015). According to the implementation update on Prüm decisions 
published in November 2018, Portugal is currently automatically exchanging data with 19 countries (Council of the European Union, 2018).

By the end of 2018, the Portuguese database included nearly 11,774 profiles, 9,128 of which are profiles of convicted offenders, 143 of laboratory staff and four of volunteers (Supervisory Board of DNA Profiles Database in Portugal, 2020). These DNA profiles stored in the Portuguese DNA database equate to $0.09 \%$ of the Portuguese population, a figure substantially lower than in many other EU member states.

The initial discrepancy between the EU's credo of borderless data circulation and the de facto situation in Portugal, which restricts what DNA data can be collected and exchanged, can be explained by a particular mode of ordering, one that results in latently re-bordered bio-borders. The regulations and legislative frameworks determining the collection, use, and retention of particular DNA data in Portugal are derived from a protective regime in terms of personal data and genetic privacy, which aims to protect national data subjects ${ }^{5}$. Portugal's constitutionally driven approach to bio-borders has determined a strictly lawful application of the DNA technology which opposes expansive data exchange.

Regarding the biometric techno-scientific infrastructure, the scientific standards are meant to respect genetic privacy (while not interfering with the coding region of the DNA) and to be in line with international standards, which include the laboratory standards (ISO 17025) as well as the scientific standards of European forensic genetics (the selection of genetic markers conforming with the European Standard Set). Regarding the procedural process of defining DNA markers, article 12(2) of the DNA database law in Portugal makes adaptations to changes in international standards regarding DNA markers a protracted and complex process:

DNA markers to incorporate in the file DNA profiles are fixed after consultation with the Commission National Data Protection (NCDP), by joint order members of the Government responsible for the justice and health, in accordance with international standards and scientific knowledge on the matter [Forensic Genetics Policy Initiative, (2017), p.75].

However, as a result of the ordering linked to the constitutive component of the technical database infrastructure, we find some re-bordering happening in opposition to the European imperative to expand transnational DNA data flow. Although professionals involved in the provision of the technical database infrastructure are committed to technical connectivity and thus are committed to making bio-borders permeable, the restrictive nature of the Portuguese legislation (Santos et al., 2013) has impacted on the data categories made available for data exchange. The commitment to connectivity is expressed, firstly, in the decision to use CODIS - the software used by most of the member states - to facilitate data exchange; connecting to other CODIS run databases is thus relatively easy. Secondly, it is expressed through the relatively quick progress made in connecting with the member states: Portugal has established connections with 19 member states in around two years (Council of the European Union, 2018). Although an expansive networked installation is in place, the data traffic is nevertheless reduced, since Portugal only shares the data of convicted offenders and of crime stains (Table 1). By the end of 2017, 7,430 DNA profiles of convicted offenders and 2,346 crime stains (synonymous with the CODIS category 'forensic, unknown') were stored in the database and made accessible for data exchange.

The organisational imperatives and routines in forensic genetics dedicated to the exchange of DNA data in Portugal reflect how governance principles, such as 
commitments to high levels of data protection as well as to public accountability, are translated into operational and organisational infrastructures. The judicial entities and the forensic experts who manage the Portuguese DNA database perform routines that reveal a careful and cautious approach to data protection, security and control, and a restriction in the exchange of data with other countries aimed at protecting, in particular, national data-subjects (Machado and Frois, 2014; Frois and Machado 2016). In this context the organisational imperatives of the Supervisory Board, which oversees the operations of the Portuguese national DNA forensic database, deserve attention. The Board is responsible for providing information in the form of publically available annual reports and statistics about the DNA database and the Prüm exchange, and also reports to the Portuguese parliament [Forensic Genetics Policy Initiative, (2017), p.85].

We emphasise the role of the Supervisory Board here as an example of how non-mandatory components applied for ordering bio-borders in an accountable and transparent manner counter the Prüm system's lack of transnational public accountability. Supervisory boards are not yet a common organisational imperative accompanying DNA database systems among European member states. Although ENFSI provides the recommendation that the member states should set up an infrastructure that addresses the 'delicate role' of DNA databases in society [ENFSI DNA Working Group, (2017), p.49], it remains the responsibility of each State to translate responsible governance principles into operational routines. As an additional control mechanism, the oversight body safeguards the appropriate functioning of border-crossing data flows. With the Supervisory Board accountable to the Portuguese parliament, territorial nation-state borders are enforced in the construction of the legitimacy of permeable bio-borders towards the Portuguese people.

The Portuguese case is an illustrative example of how the particularities of judicial and legal traditions, as well as regulations foreseeing ethical oversight of DNA data exchange, partially counter the de-bordering dynamics of the EU level; while the national policy and the techno-scientific and operational infrastructures partially conform with them. In sum, the Portuguese case illustrates the latent re-bordering of bio-borders.

\section{Conclusions}

In this article, we introduced the notion of 'bio-bordering' and used the example of the Prüm system as a case of bio-bordering between the EU and its member states. More concretely, we focused on the one hand on the different modes of ordering at the EU level resulting in de-bordered bio-borders, emphasising, in particular, the legal, biometric techno-scientific, technical database and organisational infrastructures that constitute permeable bio-borders. On the other hand, we showed how the Portuguese mode of ordering has resulted in latently and partially re-bordered bio-borders.

The mandatory elements of the Prüm decisions were politically enforced without taking into consideration the significant differences between EU countries. Thus, fragmentation comes as a contingency regarding, for example, operational and organisational traditions, legislation, the nature of the criminal justice system, national variations regarding the human and economic resources to invest in forensic DNA databases, DNA profiling technologies and other kinds of police information databases.

The levelling mode of ordering, building on the distributed but collective agency of the heterogeneous actor-network at the EU level, enforced a particular version of 
bio-borders that displays the political belief that the interoperability of DNA databases is a mere technical-scientific issue. Thus, European hidden integration is partially achieved by the standardisation and harmonisation of scientific and technical procedures between laboratories and police forces based in different countries. Thereby, de-bordering occurs as a result of the virtual expansion of bio-borders through the circulation of concerned (suspect) bodies and, in consequence, DNA data into other states' territories.

In Portugal, a protective mode of ordering has been enforced, resulting in latent re-bordering dynamics that, while fully implementing the requirements of the respective EU regulations, defensively, restrictively and protectively govern the ways of making DNA data accessible. Various contingencies contribute to this mode of ordering:

1 a restrictive legislative and regulatory framework regarding inclusion criteria for the DNA database

2 the scientific standards respecting genetic privacy

3 limits to the DNA data categories made available

4 the organisational imperative to provide transparency and control permeable bio-borders through publicly available statistics and to be accountable to the Portuguese parliament, and by extension the national electorate.

From the Portuguese case and its particular national contingencies, we learn that re-bordering may not only imply the restriction of data flow, but can also mean preventing the unintended consequences of data flow, or aiming to create transparency and thus public legitimacy for the implications of bio-borders.

Re-bordering, understood as the sum of multiple distributed ordering practices aimed at maintaining a protective data-exchange regime that also puts in place safeguards, is the multiple enactment of restrictive bio-borders in order to counter the ambition of expansive data exchange. We understand latent re-bordering here to also be a manifestation of the persistent 'hidden fragmentation' of the EU. By relying on state autonomy, this protective mode of ordering enacts a version of bio-borders that comes with, at least, disinterest in 'fixing' or 'appropriating' the obstructions to expansive borderless data exchange.

Finally, what we observed is that national regimes are concerned about their own data subjects' rights - and less about others' rights - when maintaining stricter data protection rules, and concerned about accountability towards their own electorate when installing oversight mechanisms.

\section{Acknowledgements}

This work has received funding from the European Research Council (ERC) under the EU's Horizon 2020 research and innovation programme (Consolidation grant, agreement No. 648608), within the project 'EXCHANGE - Forensic geneticists and the transnational exchange of DNA data in the EU: Engaging science with social control, citizenship and democracy', led by Helena Machado and hosted at the Institute for Social Sciences of at the University of Minho, Portugal. Furthermore, we would like to thank the editors of the special issue, Ildikó Plájás, Rafaela Granja and the anonymous reviewers for their valuable comments on earlier versions of this article. Additionally, we 
are grateful to Filipe Santos, for his suggestion of applying the term of 'bio-borders' to the transnational exchange of DNA data, and to Sara Matos and Filipa Queirós for providing important insights from their fieldwork experience in Portugal.

\section{References}

Aas, K.F. (2011) 'Crimmigrant' bodies and bona fide travelers: surveillance, citizenship and global governance', Theoretical Criminology, Vol. 15, No. 3, pp.331-346.

Amoore, L. (2006) 'Biometric borders: governing mobilities in the war on terror', Political Geography, Vol. 25, No. 3, pp.336-351.

Broeders, D. (2007) 'The new digital borders of europe: eu databases and the surveillance of irregular migrants', International Sociology, Vol. 22, No. 1, pp.71-92.

Commission of the European Union (2016) September Infringements' Package - Key Decisions [online] http://europa.eu/rapid/press-release_MEMO-16-3125_EN.htm (accessed 13 February 2018).

Council of the European Union (2005) Prüm Convention, Brussels.

Council of the European Union (2008a) Council Decision 2008/615/JHA of 23 June 2008 on the Stepping up of Cross-Border Cooperation, Particularly in Combating Terrorism and CrossBorder Crime, Official Journal of the European Union [online] http://eur-lex.europa.eu/legalcontent/EN/TXT/PDF/?uri=CELEX:32008D0615\&from=EN (accessed 21 July 2017).

Council of the European Union (2008b) Council Decision 2008/616/JHA of 23 June 2008 on the Implementation of Decision 2008/615/JHA on the Stepping up of Cross-Border Cooperation, Particularly in Combating Terrorism and Cross-Border Crime, Official Journal of the European Union [online] http://eur-lex.europa.eu/LexUriServ/LexUriServ.do?uri=OJ:L:2008: 210:0012:0072:EN:PDF (accessed 21 July 2017).

Council of the European Union (2015) Working Party on Information Exchange and Data Protection (DAPIX)' - Implementation of the provisions on information exchange of the 'Prüm Decisions, 5010/7/15 REV 7, Brussels (accessed 21 July 2017).

Council of the European Union (2018) Working Party on Information Exchange and Data Protection (DAPIX) - Implementation of the provisions on information exchange of the 'Prüm Decisions, 5077/5/18 REV5, p.16 [online] http://data.consilium.europa.eu/doc/document/ST5081-2017-INIT/en/pdf (accessed 21 July 2017).

Curtin, D. (2018) 'Second order secrecy and europe's legality mosaics', West European Politics, Vol. 41, No. 4, pp.846-868.

Dijstelbloem, H. and Broeders, D. (2015) 'Border surveillance, mobility management and the shaping of non-publics in Europe', European Journal of Social Theory, Vol. 18, No. 1, pp.21-38.

ENFSI DNA Working Group (2017) DNA Database Management Review and Recommendations, Brussels.

Forensic Genetics Policy Initiative (2017) Forensic Genetics Policy Initiative [online] http://dnapolicyinitiative.org/wiki/index.php?title=Main_Page. (accessed 31 July 2018).

Frois, C. and Machado, H. (2016) 'Modernization and development as a motor of polity and policing', in Bradford, B. et al. (Eds.): The SAGE Handbook of Global Policing, pp.391-405, Sage Publications, London.

Gabinete do Secretário -Geral (2006) Relatório anual de segurança interna 2006 [online] http://www.ansr.pt/InstrumentosDeGestao/Documents/Relat\%C3\%B3rio\%20Anual\%20de\%2 0Seguran\%C3\%A7a\%20Interna\%20(RASI)/RASI_2006.pdf (accessed 21 December 2019).

Johnson, P., Williams, R. and Martin, P. (2003) 'Genetics and forensics: making the national DNA database', Science Studies, Vol. 16, No. 2, pp.22-37.

Kolossov, V. and Scott, J. (2013) 'Selected conceptual issues in border studies', Belgeo, Vol. 4, pp.1-19. 
Latour, B. (1987) Science in Action. How to Follow Scientists and Engineers through Society, Harvard University Press, Cambridge, MA.

Latour, B. (2005) Reassembling the Social. An Introduction to Actor-Network-Theory, Oxford University Press, Oxford.

Lehtonen, P. and Aalto, P. (2017) 'Smart and secure borders through automated border control systems in the EU? The views of political stakeholders in the member states', European Security, Vol. 26, No.2, pp.207-225.

Löw, M. and Weidenhaus, G. (2017) 'Borders that relate: conceptualizing boundaries in relational space', Current Sociology Vol. 65, No. 4, pp.1-18.

Machado, H. and Frois, C. (2014) 'Aspiring to modernization. Historical evolution and current trends of state surveillance in Portugal', in Boersma, K. et al. (Eds.): Histories of Surveillance in Europe and Beyond, pp.65-78, Routledge, Oxon and New York.

Machado, H. and Granja, R. (2018) 'Ethics in transnational forensic DNA data exchange in the EU: constructing boundaries and managing controversies', Science as Culture, Vol. 27, No. 2., pp.242-264.

Machado, H. and Prainsack, B. (2012) Tracing Technologies: Prisoners' Views in the Era of CSI, Ashgate, Farnham, UK.

Machado, H. and Silva, S. (2009) 'Informed consent in forensic DNA databases: volunteering, constructions of risk and identity categorization', BioSocieties, Vol. 4, No. 4, pp.335-348.

Machado, H. and Silva, S. (2010) 'Portuguese forensic DNA database: political enthusiasm, public trust and probable issues in future practice', in Hindmarsh, R. and Prainsack, B. (Eds.): Genetic Suspects: Global Governance of DNA Profiling and Databasing, pp.218-239, Cambridge University Press, Cambridge.

McCartney, C. (2014) 'Forensic data exchange: Ensuring integrity', Australian Journal of Forensic Sciences, Vol. 47, No. 1, pp.36-48.

McCartney, C. (2017) 'Trust and the international exchange of forensic information', in Hufnagel, S. and McCartney, C. (Eds.): Trust in International Police and Justice Cooperation, pp.169-189, Bloomsbury, Oxford and Portland, Oregon.

Misa, T.J. and Schot, J. (2005) 'Introduction', History and Technology, Vol. 21, No. 1, pp.1-19.

Nuffield Council on Bioethics (2007) The Forensic Use of Bioinformation: Ethical Issues, London.

Perras, C. (2017) 'Transnational policing and its contexts: flexibility and (dis)trust', in Hufnagel, S. and McCartney, C. (Eds.): Trust in International Police and Justice Cooperation, pp.221-240, Bloomsbury, Oxford and Portland, Oregon.

Prainsack, B. and Toom, V. (2010) 'The Prüm regime. Situated dis/empowerment in transnational DNA profile exchange', British Journal of Criminology, Vol. 50, No. 6, pp.1117-1135.

Prainsack, B. and Toom, V. (2013) 'Performing the union: the Prüm decision and the European dream', Studies in History and Philosophy of Science Part C: Studies in History and Philosophy of Biological and Biomedical Sciences, Vol. 44, No. 1, pp.71-79.

Sallavaci, O. (2015) 'Cross border exchange of forensic DNA and human rights protection', Forensic Science International: Genetics Supplement Series, Vol. 5, No. 1, pp.86-88.

Sallavaci, O. (2017) 'Strengthening cross-border law enforcement cooperation in the EU: the Prüm network of data exchange', European Journal on Criminal Policy and Research, Vol. 24, No. 3, pp.219-235.

Santos, F. (2017) 'The transnational exchange of DNA data: global standards and local practices', in Jakobs, K. and Blind, K. (Eds.): Proceedings of the 22nd EURAS Annual Standardisation Condeference. Digitalisation: Challenge and Opportunity for Standardisation, Verlag Mainz, Aachen, pp.305-22. 
Santos, F. and Machado, H. (2017) 'Patterns of exchange of forensic DNA data in the European union through the Prüm system', Science \& Justice, Vol. 57, No. 4, pp.307-313.

Santos, F., Costa, S. and Machado, H. (2012) 'A Base de Dados de Perfis de DNA Em Portugal: Questões Sobre a Sua Operacionalização', in Costa, S. and Machado, H. (Eds.): A ciência na luta contra o crime: Potencialidades e limites, pp.99-118, Húmus, Vila Nova de Famalicão.

Santos, F., Machado, H. and Silva, S. (2013) 'Forensic DNA databases in European countries: is size linked to performance?', Life Sciences, Society and Policy, Vol. 9, No. 12, pp.1-13.

Scheel, S. (2013)'Autonomy of migration despite its securitisation? Facing the terms and conditions of biometric rebordering', Millennium: Journal of International Studies, Vol. 41, No. 3, pp.575-600.

Supervisory Board of DNA Profiles Database in Portugal (Conselho des Fiscalização Base de Dados de Perfis de ADN) (2020) Relatório Annual 2018 [online] https://www.cfbdadosadn.pt/ pt/atividade/Documents/Relat\%C3\%B3rio\%20Anual\%202018_CFBDP\%20ADN.pdf (accessed 15 January 2020).

Taverne, M. and Broeders, A.P.A. (2015) The Light's at the End of the Funnel! Evaluating the Effectiveness of the Transnational Exchange of DNA Profiles between the Netherlands and Other Prüm Countries, Paris Legal Publishers, Zutphen.

Toom, V. (2018) Cross-Border Exchange and Comparison of Forensic DNA Data in the Context of the Prüm Decision, Civil Liberties, Justice and Home Affairs [online] http://www.europarl.europa.eu/thinktank/en/document.html?reference=IPOL_STU(2018)6049 71 (accessed 20 December 2018).

Tsianos, V. and Karakayali, S. (2010) 'Transnational migration and the emergence of the European border regime: an ethnographic analysis', European Journal of Social Theory, Vol. 13, No. 3, pp.373-87.

Tsianos, V. S. and Kuster, B. (2016) 'Eurodac in times of bigness: the power of big data within the emerging European IT agency' Journal of Borderlands Studies, Vol. 31, No. 2, pp.235-249.

Van der Beek, K. (2011) Forensic DNA Profiles Crossing Borders in Europe (Implementation of the Treaty of Prüm), pp.1-14 [online] https://worldwide.promega.com/resources/profiles-indna/2011/forensic-dna-profiles-crossing-borders-in-europe/ (accessed 21 July 2017).

Van der Ploeg, I. (1999) 'The illegal body: 'Eurodac' and the politics of biometric identification', Ethics and Information Technology, Vol. 1, No. 4, pp.295-302.

Van Houtum, H. et al. (Eds.) (2005) B/ordering Space, Ashgate, Aldershot.

Vukov, T. and Sheller, M. (2013) 'Border work: surveillant assemblages, virtual fences, and tactical counter-media', Social Semiotics, Vol. 23, No. 2, pp.225-241.

Wallace, H., Jackson, A., Gruber, J. and Thibedeau, A. (2014) 'Forensic DNA databases: ethical and legal standards - a global review', Egyptian Journal of Forensic Sciences, Vol. 4, No. 3, pp.57-63.

Williams, R. and Wienroth, M. (2014) 'Suspects, victims and others: producing and sharing forensic genetic knowledge', in Chadwick, R. et al. (Eds.): The Right to Know and the Right Not to Know. Genetic Privacy and Responsibility, pp.71-84, Cambridge University Press, Cambridge.

Wilson, T. (2016) 'Criminal justice and global public goods: the Prüm forensic biometric cooperation model', The Journal of Criminal Law, Vol. 80, No. 5, pp.303-326. 


\section{Notes}

1 SIS is used by 31 European countries to find information about individuals and entities for national security, border control and law enforcement. A second technical version of this system, SIS II, has existed since 2013.Eurodac is the European Union's fingerprint database for identifying asylum seekers and so-called irregular border-crossers. VIS is a database containing information, including biometrics, on visa applications by Third Country Nationals requiring a visa to enter the Schengen area. The Prüm system enables the signatories to exchange data regarding DNA, fingerprints and vehicle registration of persons of concern and to cooperate against terrorism. Eurosur is an EU surveillance system that uses drones, reconnaissance aircraft, offshore sensors and satellite remote sensing to track illegal immigration into the member states of the European Union.

2 The term 'biometric data', in the context of criminal investigation, pertains to data derived from the analysis of a range of physical or biological characteristics of a person [Nuffield Council on Bioethics, (2007), p.5], which may include DNA, fingerprints, iris scans, photographs or images on CCTV cameras.

3 In this article we focus at biometric data exchange and its implications for understanding borders in the context of crime control. Scheel (2013) has used the term of 'biometric rebordering' in the context of biometric based migration control to explore how migrants develop forms of appropriation to biometric borders.

4 The Treaty of Lisbon, which entered into force in December 2009, is an international agreement that amends the two treaties which form the constitutional basis of the European Union: the Maastricht Treaty (1993) and the Treaty of Rome (1957). The Treaty of Lisbon aimed to give stronger powers to the European Parliament, and it was signed by all EU members. Opponents of the Treaty of Lisbon argued that it would centralize the EU and weaken the national parliaments.

5 In line with previous regulations, Portuguese criminal law development follows its distinct logic. The designation 'arguido' (an official suspect) gives status to an individual who has been formally charged or is under investigation. It provides certain rights, such as knowing the details of charges, but it also comes with obligations, such as the provision of a simple statement of identity [Machado and Prainsack, (2012), p.39]. 